\title{
Anticardiolipin Status in Idiopathic Infertile Nigerian Females
}

\author{
Azenabor $\mathrm{A}^{\mathbf{1}^{*}}$, Agha $\mathrm{CU}^{2}$, Ogunmola $\mathrm{IO}^{1}$, Bamiro $\mathrm{SB}^{3}$, Osiagwu DD ${ }^{1}$ \\ ${ }^{1}$ Department of Medical Laboratory Science, College of Medicine, University of Lagos \\ ${ }^{2}$ School of Medical Lab Sciences, LUTH \\ ${ }^{3}$ Department of Obstetrics and Gynaecology, College of Medicine, University of Lagos.
}

*Corresponding Author: Azenabor A, Department of Medical Laboratory Science, College of Medicine, University of Lagos

\section{INTRODUCTION}

Idiopathic infertility refers to failure to conceive in a couple who have no definitive cause for infertility. The incidence of idiopathic infertility depends on the selection and age of the study population and to some extent on fertility evaluations [1]. This may account for the variations reported in different studies, though were all in the range of $10-20 \%$ [2,3,4]. Several theories have been tendered on the etiology of unexplained infertility. This includes diminished ovarian reserve [5], estradiol/progesterone ratio [6], impaired ovum pick up [7] and deregulation of the immune system [8]. Autoimmune processes and mechanisms are considered as contributing factors in some cases of unexplained infertility in both men and women, particularly when they are directed to antigens expressed in tissues and cells of the reproductive tract and genital secretion. Presence of antibodies to zona pellucida and endometrial antigens in women, are considered possible causes of infertility in a fraction of patients with unexplained infertility. Of particular importance are antiphospholipid antibodies, which include anticardiolipin among others [9]. Even though these antibodies have been found in individuals without any clinical consequences, approximately $15-20 \%$ of patients with these antibodies has been reported to have obstetric complications and up to $50-75 \%$ of these pregnancies was shown to exhibit poor outcomes [10]. In a more recent study, a high prevalence of $\operatorname{IgG}$ and IgM anti-cardiolipin antibodies were observed in women with unexplained infertility, unexplained recurrent abortion and intrauterine fetal death [11]. The mechanism of association of anticardiolipin antibodies with idiopathic infertility is complex and incompletely understood, though a previous study was able to provide a link between the incidences of anticardiolipin antibodies with polycystic ovarian syndrome - PCOS [12], while hyperprolactinaemia was postulated to affect fecundity not only by affecting ovulation and implantation through hormonal but also through immunological processes [13]. It is instructive to note that available reports on antiphospholipid antibodies in Nigeria females were on women with pregnancy complications, where a prevalence of $9.3 \%$ and $2.3 \%$ of lupus anticoagulant and anticardiolipin IgG antibodies respectively were observed [14]. Interestingly, among the five (5) cases of antiphospholipid antibody detected in females observed in Sagamu, Nigeria, pregnancy loss was the most frequent presentation, and anticardiolipin IgG was more commonly seen [15]. However, not much is known about the status of anticardiolipin antibodies in Nigerian females with unexplained infertility. The objective of this study includes the following:

1. Comparative assessment of the incidence of anticardiolipin antibodies ( $\operatorname{IgG}$ and $\operatorname{IgM})$ in idiopathic infertile Nigerian females and those with other known etiologies.

2. Comparison of the plasma levels of anticardiolipin antibodies (IgG and $\operatorname{IgM}$ ) in idiopathic infertile Nigerian females and those with known etiologies.

3. Evaluation of a possible association between anticardiolipin antibodies and female reproductive hormones.

\section{MeTHODS}

This was a descriptive, cross sectional analytical study conducted on 176 women aged between $28-42$ years attending the infertility clinic of the Lagos University Teaching Hospital (LUTH) Idi-Arabia, 
Lagos. Inclusion criteria included women with a normal menstrual cycle ranging from 26-32 days, and not to have taken any contraceptive pills in the past one year. Exclusion criteria included women below 28 years of age, pregnant women, menopausal women, women with diabetes mellitus, thyroid disorders, connective tissue disease, autoimmune diseases, previous history of thrombo-embolism and women on immunosuppressive drugs or immune modulators. Ethical approval was obtained from the Health Research and Ethics Committee of the College of Medicine, University of Lagos, and Idi-Araba (Approval no - CM/HREC/MLS/05/16/006). Informed consent was obtained from the study subjects. Case report forms were administered in order to obtain information on biodata, histories pertaining to known illnesses, and menstrual cycle.

\subsection{Laboratory Analyses}

Fasting venous blood samples (5mls) were collected on the $14^{\text {th }}$ day of a $28^{\text {th }}$ day menstrual cycle from each subject for LH, FSH and anticardiolipin estimations and on the $23^{\text {rd }}$ day of the cycle for prolactin, and progesterone. Anticardiolipin antibodies (IgG and $\operatorname{IgM})$ and the reproductive hormones were estimated by enzyme linked immunosorbent (ELISA) method. The name of the kits used for IgG and IgM anticardiolipins was DiaMetra (Italy) while the Rapid lab kits (UK) was used for the reproductive hormones. The intra assay coefficient of variation for IgG anticardiolipin, IgM anticardiolipin, progesterone, prolactin , FSH and LH were $12.8 \%, 12.7 \%, 4 \%, 8.1,2.9$ and 5.9\% respectively while the inter - assay coefficient of variation for $\operatorname{IgG}$ anticardiolipin, $\operatorname{IgM}$ anticardiolipin, progesterone, prolactin , FSH and LH were $11.8 \%$. 11.5\%, 9.3\%, 9.7\%, 3.2\% and 9.0\% respectively.

\subsection{Diagnostic Criteria}

1. Women with luteal phase progesterone level less than $18 \mathrm{nmol} / 1$ despite normal levels of $\mathrm{LH}, \mathrm{FSH}$ and prolactin were anovulatory

2. Women with prolactin levels above 550miu/l were classified as Hyperprolactinaemic despite normal levels of $\mathrm{LH}, \mathrm{FSH}$ and progesterone.

3. Women with LH/FSH ratio greater than 3.0 were classified as having polycystic ovarian syndrome [16].

4. Women with normal hormonal profile results with their spouse already certified fertile during previous medical examination were classified as idiopathic or unexplained infertility.

5. Positive IgG and IgM anticardiolipins refer to serum levels $\geq 10 \mathrm{Au} / \mathrm{ml}$ [17].

\subsection{Statistical Analysis}

The results generated from this study were subjected to statistical analysis using Statistical Package for Social Sciences (SPSS) version 17. Quantitative data was expressed as mean \pm SEM. The difference between two means was assessed by student' $t$ ' test. Within group and between group analyses was done using one way analysis of Variance (ANOVA). Post Hoc analysis was used to establish where significance lies in ANOVA. Categorical variables were assessed by Chi- square. Pearson's correlation coefficient was used to establish associations between groups. The level of statistical significance in all studies was defined as $\mathrm{p}<0.05$.

\section{RESULTS}

The mean age (standard error of mean - SEM) and age range of the study subjects were 34(0.65) years and $22-42$ years respectively. The number and proportions of females with idiopathic infertility were $64(36.4 \%)$, anovulatory disorder 60 (34.1\%), hyperprolactinaemia $26(14.8 \%)$, and polycystic ovarian syndrome $26(14.8 \%)$. While increased levels (mean \pm SEM) of IgG anticardiolipin was observed in idiopathic infertility $(8.01 \pm 3.05 \mathrm{Au} / \mathrm{ml})$ when compared with hyperprolactinaemia $(7.88 \pm 0.49 \mathrm{Au} / \mathrm{ml})$, PCOS $(6.07 \pm 0.36 \mathrm{Au} / \mathrm{ml})$ and anovulation $(5.99 \pm 0.34 \mathrm{Au} / \mathrm{ml})(\mathrm{f}=7.89, \mathrm{p}=0.000) ; \operatorname{IgM}$ anticardiolipin showed significantly higher levels in PCOS $(10.14 \pm 0.51 \mathrm{Au} / \mathrm{ml})$ when compared with other groups ( $\mathrm{f}=$ $4.60, \mathrm{p}=0.004)$. Incidence of $\operatorname{IgG}$ anticardiolipin antibodies were more prominent $(65 \%)$ in idiopathic infertility, while IgM anticardiolipin recorded higher incidence (40.5\%) among subjects with anovulatory disorders. An inverse correlation of $\operatorname{IgG}$ anticardiolipin was observed with prolactin in anovulatory disorder $(r=-0.291, p=0.024)$ and progesterone in idiopathic cases $(r=0.268, p=0.032)$. 


\section{DIS CUSSION}

Autoimmune processes and mechanisms are implicated as one of the underlying causes of unsuccessful attempts for having a child, especially when all other reproductive hormones are normal. Unfortunately, infertile women usually display no signs or symptoms that reflect an autoimmune disease; hence unlike reproductive hormones, immunological parameters are not commonly sought for when investigating cases of infertility. This study was designed to assess the levels of anticardiolipin antibodies (IgG and $\operatorname{IgM}$ ) in peripheral blood of Nigerian females with unexplained infertility compared with those of known etiologies and its possible associations with reproductive hormones.

In this study, hyperprolactinaemia was observed in $14.8 \%$ of the study subjects, while anovulatory disorder, polycystic ovarian syndrome and idiopathic causes were noticed in $34.1 \%, 14.8 \%$ and $36.4 \%$ respectively. Assessment of anticardiolipin status in these groups showed increased mean levels IgG and IgM anticardiolipin in subjects with unexplained infertility and polycystic ovarian syndrome respectively when compared with other known etiologies. The significant increase of IgG anticardiolipin levels may suggest the existence of a secondary immune response in most of the idiopathic infertile subjects. Thus, previous immunization with phospholipids, phospholipid - binding proteins or cross reactive antigen derived from infectious agents could be hypothesized. It is also worth mentioning that regardless of the etiology of infertility, more subjects show positivity (42\%) for IgM anticardiolipin ( $\geq 10 \mathrm{Au} / \mathrm{ml}$ ); however, among the $\mathrm{IgG}$ positive cases $(22.7 \%)$, a greater percentage of them $(65 \%)$ were those whose cause of infertility could not be traced to any hormonal imbalance as against $35.1 \%$ of IgM positivity rate of the same group.

Whilst IgM anticardiolipin positivity rates of $40.5 \%, 8.1 \%, 35.1 \%$ and $16.2 \%$ in anovulation, hyperprolactinaemia, unexplained infertility and polycystic ovarian syndrome respectively was observed, IgG anticardiolipin positivity rates were observed to be lower in the same groups, save for hyperprolactinaemic and idiopathic groups, where higher percentage of $20 \%$ and $65 \%$ respectively were documented. The high positive rate of $\operatorname{IgM}$ anticardiolipin observed in anovulatory disorder is consistent with that reported in other studies $[18,19]$. This may be due to the ability of IgM antibodies to cause tiny blood clots in vessels preventing blood rich in hormones ( $\mathrm{LH}$ and FSH) from reaching the ovaries and other reproductive organs leading to reduced follicular development and maturation [20, 21], which could also be another possible cause of anovulation in these subjects.

It is worthy of note that our reported incidence of $\operatorname{IgG}$ anti-cardiolipin antibodies in subjects with hyperprolactinaemia corroborates the reports of a previous study [22]. This could be attributed to the fact that prolactin enhances antibody production. Available evidence also suggests that hypophysectomy also suppresses the production of antibodies [23]. It is also instructive to note that prolactin is not only secreted by the anterior pituitary gland but also by extra-pituitary sites including the immune cells. Consequently, the elevated prolactin levels in these subjects, according to Bellis et al, could be due to coordinated bidirectional communications between prolactin and the immune system. This view was also supported by Abdul - Saud et al, who reported increased synthesis of interferon gamma and interleukin 2 by prolactin leading to production of antibodies especially those of the $\operatorname{IgG}$ type.

Pearson correlation coefficient was carried out to establish association of anticardiolipin status (IgG and $\mathrm{IgM}$ ) with reproductive hormones in different infertile group studied. An inverse correlation of IgG anticardiolipin was observed with prolactin in anovulatory disorder $(\mathrm{r}=-0.291, \mathrm{p}=0.024)$ and progesterone in idiopathic causes $(\mathrm{r}=0.268, \mathrm{p}=0.032)$. While $\mathrm{IgM}$ anticardiolipin show negative correlation with $\mathrm{LH} / \mathrm{FSH}$ ratio in hyperprolactinaemic subjects $(\mathrm{r}=-0.268, \mathrm{p}=0.032)$, a positive correlation of IgM was shown with progesterone in polycystic ovarian syndrome $(r=0.675, p=0.000)$. It can thus be inferred from the correlation studies that anticardiolipin status could influence reproductive hormones. This somewhat agrees with a previous study by Osamanagouglou et al [24] who reported an inverse relationship between progesterone and anticardiolipin antibodies in idiopathic infertile group.

Although not part of the objective of this study, a cursory assessment of the association of IgG anticardiolipins with IgM anticardiolipin antibodies showed that these antibodies were independent of each other $(r=-0.022, p=0.768)$. Presence of current infection reflected by IgM anticardiolipin status of infertile subjects is not influenced by previous IgG status. The mechanism involved may be due to the complex nature of autoimmune processes. 


\section{Results}

Table1. Mean levels of anticardiolipin antibodies (IgM and $\operatorname{Ig} G$ ) in different etiologies of Infe rtility.

\begin{tabular}{|l|l|l|l|l|l|l|}
\hline $\begin{array}{l}\text { Anticardiolipin } \\
\text { antibodies }\end{array}$ & $\begin{array}{l}\text { Anovulation } \\
\mathbf{n}=\mathbf{6 0}\end{array}$ & $\begin{array}{l}\text { Hyperprolactinaemia } \\
\mathbf{n = 2 6}\end{array}$ & $\begin{array}{l}\text { PCOS } \\
\mathbf{n = 2 6}\end{array}$ & $\begin{array}{l}\text { Idiopathic } \\
\text { Infertility } \\
\mathbf{n = 6 4}\end{array}$ & f values & $\begin{array}{l}\mathbf{p} \\
\text { values }\end{array}$ \\
\hline IgM & $9.73 \pm 0.30$ & $7.92 \pm 0.50$ & $\begin{array}{l}10.14 \quad \pm \\
0.51\end{array}$ & $9.64 \pm 0.30$ & 4.60 & $0.004^{*}$ \\
\hline IgG & $5.99 \pm 0.34$ & $7.88 \pm 0.49$ & $\begin{array}{l}6.07 \\
\pm 0.36\end{array}$ & $8.01 \pm 3.05$ & 7.89 & $0.000^{*}$ \\
\hline
\end{tabular}

Values are presented as mean \pm SEM. Statistical evaluation was performed using one way analysis of variance (ANOVA). *Significant. PCOS - Polycystic Ovarian Syndrome, IgM-Immunoglobulin M, Ig G-Immunoglobulin $G$.

Table2. Post Hoc analysis of anticardiolipin antibodies (IgM and IgG) in Groups of Infertile Females studied

\begin{tabular}{|c|c|c|c|c|}
\hline Subjects & Groups & Mean difference & Standard error & p value \\
\hline \multicolumn{5}{|l|}{ IgM } \\
\hline \multirow[t]{3}{*}{ Anovulation } & Hyperprolactinaemia & 1.09 & 0.56 & $0.002 *$ \\
\hline & Idiopathic & 0.89 & 0.43 & 0.838 \\
\hline & PCOS & -0.42 & 0.56 & 0.462 \\
\hline \multirow[t]{3}{*}{ Hyperprolactinaemia } & Anovulation & -1.81 & 0.56 & $0.002 *$ \\
\hline & Idiopathic & -1.72 & 0.56 & $0.002^{*}$ \\
\hline & PCOS & -2.22 & 0.67 & $0.001^{*}$ \\
\hline \multirow[t]{3}{*}{ Idiopathic } & Anovulation & -0.09 & 0.43 & 0.838 \\
\hline & Hyperprolactinaemia & 1.72 & 0.56 & $0.002 *$ \\
\hline & PCOS & -0.50 & 0.56 & 0.368 \\
\hline \multirow[t]{3}{*}{ PCOS } & Anovulation & 0.42 & 0.56 & 0.462 \\
\hline & Hyperprolactinaemia & 2.22 & 0.67 & $0.001 *$ \\
\hline & Idiopathic & 0.50 & 0.56 & 0.368 \\
\hline \multicolumn{5}{|l|}{ IgG } \\
\hline \multirow[t]{3}{*}{ Anovulation } & Hyperprolactinaemia & -1.89 & 0.63 & $0.003^{*}$ \\
\hline & Idiopathic & -2.01 & 0.48 & $0.000^{*}$ \\
\hline & PCOS & -0.08 & 0.63 & 0.899 \\
\hline \multirow[t]{3}{*}{ Hyperprolactinaemia } & Anovulation & 1.89 & 0.63 & $0.003^{*}$ \\
\hline & Idiopathic & -0.12 & 0.62 & 0.844 \\
\hline & PCOS & 1.81 & 0.74 & $0.015^{*}$ \\
\hline \multirow[t]{3}{*}{ Idiopathic } & Anovulation & 2.01 & 0.48 & $0.000^{*}$ \\
\hline & Hyperprolactinaemia & 0.12 & 0.62 & 0.844 \\
\hline & PCOS & 1.93 & 0.62 & $0.002 *$ \\
\hline \multirow[t]{3}{*}{ PCOS } & Anovulation & 0.08 & 0.63 & 0.899 \\
\hline & Hyperprolactinaemia & -1.81 & 0.74 & $0.015^{*}$ \\
\hline & Idiopathic & -1.93 & 0.62 & $0.002^{*}$ \\
\hline
\end{tabular}

*significant at $p<0.05$

Table3. Prevalence of subjects positive for $\operatorname{Ig} G$ and $\operatorname{Ig} M$ antibodies

\begin{tabular}{|l|l|l|l|l|l|l|}
\hline Anticardiolipin & $\begin{array}{l}\text { Anovulation } \\
\mathbf{n}(\boldsymbol{\%})\end{array}$ & $\begin{array}{l}\text { Hyperprol actinae mia } \\
\mathbf{n}(\boldsymbol{\%})\end{array}$ & $\begin{array}{l}\text { Idiopathic } \\
\mathbf{n}(\boldsymbol{\%})\end{array}$ & $\begin{array}{l}\text { PCOS } \\
\mathbf{n}(\boldsymbol{\%})\end{array}$ & f value & p value \\
\hline $\begin{array}{l}\text { IgM } \\
(>\mathbf{1 0 A u} / \mathbf{m l})\end{array}$ & $30(40.5)$ & $6(8.1)$ & $26(35.1)$ & $12(16.2)$ & 5.630 & 0.131 \\
\hline IgG (>10Au/ml) & $4(10)$ & $8(20)$ & $26(65)$ & $2(5)$ & 24.790 & 0.000 \\
\hline
\end{tabular}

PCOS - Polycystic ovarian syndrome, $n=$ Number, $\%$ - percentage 
Table4. Pearson correlation Coefficient of anticardiolipin antibodies (IgM and IgG) with reproductive Hormones in Different Infertile Groups

\begin{tabular}{|c|c|c|c|}
\hline $\begin{array}{l}\text { Infertile Subjects } \\
(\mathrm{n}=176)\end{array}$ & $\begin{array}{l}\text { Reproducti ve } \\
\text { Hormones }\end{array}$ & $\begin{array}{l}\text { IgM } \\
\mathbf{r}(\mathbf{p})\end{array}$ & $\begin{array}{l}\text { IgG } \\
\mathbf{r}(\mathbf{p})\end{array}$ \\
\hline $\begin{array}{l}\text { Anovulatory Disorder } \\
(n=60)\end{array}$ & $\begin{array}{l}\text { LH } \\
\text { FSH } \\
\text { PRL } \\
\text { PROG } \\
\text { LH/FSH }\end{array}$ & $\begin{array}{ll}0.152 & (0.246) \\
0.198 & (0.130) \\
-0.239 & (0.066) \\
0.043 & (0.742) \\
0.150(0.919)\end{array}$ & $\begin{array}{ll}0.028 & (0.833) \\
0.238 & (0.067) \\
-0.291 & (0.024)^{*} \\
-0.066 & (0.619 \\
-0.169 & (0.198)\end{array}$ \\
\hline $\begin{array}{l}\text { Hyperprol actinae mia } \\
(\mathrm{n}=26)\end{array}$ & $\begin{array}{l}\text { LH } \\
\text { FSH } \\
\text { PRL } \\
\text { PROG } \\
\text { LH/FSH }\end{array}$ & $\begin{array}{ll}0.371 & (0.062) \\
0.057 & (0.783) \\
0.151 & (0.461) \\
-0.281 & (0.165) \\
-0.522 & (0.006)^{*}\end{array}$ & $\begin{array}{l}0.46(0.824) \\
0.193(0.345) \\
0.190(0.352) \\
-0.242(0.233) \\
0.196(0.336)\end{array}$ \\
\hline $\begin{array}{l}\text { Idiopathic } \\
(\mathrm{n}=64)\end{array}$ & $\begin{array}{l}\text { LH } \\
\text { FSH } \\
\text { PRL } \\
\text { PROG } \\
\text { LH/FSH }\end{array}$ & $\begin{array}{l}-0.056(0.660) \\
-0.050(0.692) \\
0.177(0.161) \\
-0.136(0.282) \\
-0.016(0.897)\end{array}$ & $\begin{array}{l}0.060(0.637) \\
0.022(0.862) \\
0.018(0.889) \\
-0.268(0.032)^{*} \\
0.068(0.591)\end{array}$ \\
\hline $\begin{array}{l}\text { PCOS } \\
(n=26)\end{array}$ & $\begin{array}{l}\text { LH } \\
\text { FSH } \\
\text { PRL } \\
\text { PROG } \\
\text { LH/FSH }\end{array}$ & $\begin{array}{ll}0.245 & (0.228) \\
0.246 & (0.225) \\
0.292 & (0.148) \\
0.675 & (0.000)^{*} \\
-0.032 & (0.876)\end{array}$ & $\begin{array}{ll}0.235 & (0.247) \\
0.193 & (0.345) \\
0.372 & (0.061) \\
0.068 & (0.740) \\
0.068 & (0.742)\end{array}$ \\
\hline
\end{tabular}

Statistical evaluation was done using Pearson correlation coefficient. A value ofp less than 0.05 was accepted as significant.

\section{CONCLUSiON}

From the empirical data generated, the $\operatorname{IgG}$ and IgM status of anticardiolipin antibodies were significantly higher in infertile subjects with unexplained causes and polycystic ovarian syndrome respectively. A higher prevalence of anticardiolipin ( $\operatorname{IgG})$ was observed in infertile subjects with unexplained causes. Anticardiolipin is significantly associated with some of the female reproductive hormones

\section{ACKNOWLEDGEMENTS}

We wish to acknowledge Mr. A. Lawal who assisted in the statistical analysis of Data.

\section{REFERENCES}

[1] Fisch P, Casper RF, Brown SE, Wrixon W, Collins JA, Reid RL, Simpson C. Unexplained infertility: Evaluation of treatment with clomiphene citrate and human chorionic gonadotropin. Fertil Steril 1989; 51: 828-833.

[2] Lessey BA, Castelbaum AJ, Sawin SW, Sun J. Integrins as markers of uterine receptivity in women with primary unexplained infertility. Fertil Steril 1995; 63: 535-542.

[3] Guzic DS, Grefenstette I, Baffone K, Berga SL, Krasnow JS, Stovall DW, Naus GJ. Infertility evaluation infertile women: a model for assessing the efficacy of infetility testing. Hum Reprod 1994; 9: 2306-2310.

[4] Miller JH, Weinberg RK, Canino NL,Klein NA, Soules MR. The pattern of infertility diagnoses in women of advanced reproductive age. Am J Obstet Gynecol 1999;181: 952-957.

[5] Luborsky J, Llanes B, Roussev R, Coulam C. Ovarian antibodies, FSH and inhibin B: independent markers as sociated with unexplained infertility. Hum Reprod 2000; 15: 1046-1051.

[6] Omland AK, Fedorcsak P, Storeng R, Dale PO, Åbyholm T, Tanbo T. Natural cycle IVF in unexplained, endometriosis-associated and tubal factor infertility. Hum Reprod 2001; 16: 2587-2592.

[7] Ahmad-Thabet SM. The fimbrio-ovarian relation and its role on ovum picking in unexplained infertility: the fimbrio-ovarian accessibility test. J Obstet Gynaecol Res 2000; 26: 65-70.

[8] Jasper MJ, Tremellen KP, Robertson SA. Primary unexplained infertility is associated with reduced expression of the T-regulatory cell transcription factor Foxp3 in endometrial tissue. Molecular Human Reproduction 2006; 12 (5): 301-308.

[9] Sheth F, Andreuix J, Ewers E, Kosyakova N, Weise A, Sheth H. Characterization of SSMC by FISH and Molecular techniques. Eur J Med Genet 2011; 54;247-55 
[10] Branch DW, Peaceman AM, Druzin M. Amulticenter, placebo-controlled pilot study of intravenous immune globulin treatment of antiphospholipid syndrome during pregnancy. American Journal of Obstetrics and Gynecology 2000; 182 (1):122-127.

[11] Bouvier S, Cochery-Nouvellon E, LavigneLissalde G. Comparative incidence of pregnancy outcomes in treated obstetric antiphos pholipid syndrome: the NOH-APS observational study. Ann Intern Med 2015; 162 (601): 92.

[12] Reimand, I. Talja, K. Metskula, U. Kadastik, K. Matt, and R. Uibo (2001) Autoantibody studies of female patients with reproductive failure. Journal of Reproductive Immunology 2001; 51 (2):167-176.

[13] Gleicher, N. Autoantibodies and pregnancy loss. Lancet (1994); 343: 747-748.

[14] Akinbami A, Akanmu A, Afolabi B, Wright K, Dada M, Dosunmu A. Prevalence of antiphospholipid antibodies in pregnant women in a secondary health care institution in lagos. Internet J Hematolog 2009; 6

[15] Adelowo OO, Oguntona S. Antiphospholipid syndrome in Nigeria: Report of five cases. East Af Med J 2009; 86: $94-6$

[16] Roberts WL, McMillin GA, Burtis CA, Bruns DE. Reference Information for the Clinical Laboratory Blood gases. In Tietz fundamentals of Clinical Chemistry 2008; $836-873$.

[17] Harris EN. Evaluation of the anti - cardiolipin antibody test: report of an international workshop; Clin Exp. Immunol 1987; 68: 215 -222.

[18] Radojcic L, Marjanovic S, Vicovac L. Kataranovski M. Anticardiolipin Antibodies in Women with Idiopathic Infertility. Physiological Research 2004; (53): 91-96.

[19] Marai I, Carp H, Shai S, Shabo R. Fishman G, Shoenfeld, Y. Autoantibody Panel Screening in Recurrent Miscarriages. American Journal of Reproductive Immunology 2004; 51: 235-240.

[20] Koike, T. Antiphospholipid Antibodies in Arterial Thrombosis. Annals of Medicine 2000; 32: $27-31$.

[21] Hasan A, Sh Al- Duliami A.A, Al-Zubiadi R.O. Serum Anti-Cardiolipin among Women with Recurrent abortion in Diyala Province. Diyala Journal for Pure Sciences 2010; (6) : 86-95.

[22] Abdul - Saoud AM, Abdullah E, Hassan AS. Impact of anticardiolipin antibodies and hyperprolactinaemia on laboratory, immunological and histopatholiogical parameters of lupus nephritis. Egypt Rheumatol Rehab 1999; 26 (4): 893-909.

[23] De Bellis A, Bizzaro A, Pivonello R, Lombardi G, Bellastella A. Prolactin and autoimmunity. Pituitary $2005 ; 8: 25-30$

[24] Osamanagouglou M.A, Erdogan I; Emimagouglou S; Karahan S.C, Ozgun S, Can G Bozkaya, H. The diagnostic value of beta human chorionic gonadotrophin, Progesterone, CA125 in the prediction of abortions. J. Obstet. Gynecol: 2010; 30 (3); 288-93.

Citation: A. Azenabor et al., "Anticardiolipin Status in Idiopathic Infertile Nigerian Females", International Journal of Clinical Chemistry and Laboratory Medicine (IJCCLM), vol. 4, no. 2, pp. 5-10, 2018. http://dx.doi. org/10.20431/2455-7153.0402002

Copyright: (c) 2018 Authors. This is an open-access article distributed under the terms of the Creative Commons Attribution License, which permits unrestricted use, distribution, and reproduction in any medium, provided the original author and source are credited. 